\title{
Penerapan Bayesian Network dalam Memodelkan Kondisi Ekonomi Hijau Indonesia di Era Pandemi Berdasarkan Big Data
}

\author{
(Bayesian Network Implementation for Modelling Indonesia's Green Economy Condition Based on \\ Big Data) \\ Salwa Rizqina Putri ${ }^{*}$, Thosan Girisona Suganda ${ }^{2}$, Setia Pramana ${ }^{1,2}$ \\ ${ }^{1}$ Program Studi Komputasi Statistik, Politeknik Statistika STIS \\ ${ }^{2}$ Direktorat Analisis dan Pengembangan Statistik, Badan Pusat Statistik \\ Jalan Otto Iskandardinata No.64C, Jatinegara, Jakarta Timur, Daerah Khusus Ibukota Jakarta 13330 \\ E-mail::221810596@stis.ac.id, ${ }^{2}$ thosan@bps.go.id, ${ }^{3}$ setia.pramana@ stis.ac.id
}

\begin{abstract}
ABSTRAK
Untuk mendukung pertumbuhan ekonomi hijau Indonesia, diperlukan analisis terkait aktivitas ekonomi di masa pandemi dan keterkaitannya dengan kondisi lingkungan. Akan tetapi, penelitian terkait masih belum pernah dilakukan sebelumnya. Penelitian ini bertujuan untuk menerapkan pendekatan Bayesian Network dalam memodelkan kondisi ekonomi hijau Indonesia di masa pandemi berdasarkan aktivitas ekonomi, kualitas udara, tingkat mobilitas penduduk, dan kasus positif Covid-19 yang diperoleh melalui big data. Model Bayesian Network yang dikonstruksi secara manual dengan algoritma Maximum Spanning Tree dipilih sebagai model terbaik dengan rata-rata akurasi 5-Fold Cross Validation dalam memprediksi empat kelas PDRB sebesar 0,83. Model tersebut menunjukkan bahwa kondisi ekonomi Indonesia di era pandemi secara langsung dipengaruhi oleh intensitas cahaya malam (NTL) yang menunjukkan aktivitas ekonomi, kualitas udara (AQI), dan kasus positif Covid-19. Analisis parameter learning menunjukkan bahwa pertumbuhan ekonomi provinsi-provinsi Indonesia masih cenderung belum sejalan dengan terpeliharanya kualitas udara sehingga usaha untuk mencapai kondisi ekonomi hijau masih perlu ditingkatkan.
\end{abstract}

Kata kunci: Ekonomi Hijau, Pandemi, Big Data, Bayesian Network

\section{ABSTRACT}

To support Indonesia's green economic growth, it is necessary to analyze economic activity during the pandemic and its relationship to environmental conditions. However, related research has never been done before. This study aims to apply the Bayesian Network approach in modeling Indonesia's green economy conditions during the pandemic based on economic activity, air quality, population mobility levels, and positive cases of Covid-19 obtained through big data. The Bayesian Network model that was constructed manually with the Maximum Spanning Tree algorithm was chosen as the best model with an average 5-Fold Cross Validation accuracy in predicting four classes of GRDP of 0.83. The model shows that Indonesia's economic conditions in the pandemic era are directly influenced by the intensity of night light (NTL) which shows economic activity, air quality (AQI), and positive cases of Covid-19. Analysis of learning parameters shows that the economic growth of the Indonesian provinces still tends not to be in line with the maintenance of air quality so that efforts to achieve green economic conditions still need to be improved.

Keywords: Green Economy, Pandemic, Big Data, Bayesian Network

\section{PENDAHULUAN}

Pandemi Covid-19 di berbagai belahan dunia, termasuk Indonesia, belum menunjukkan tanda akan segera berakhir. Berdasarkan penghitungan kasus positif Covid-19 di dunia pada 28 Juli 2021, Indonesia menempati posisi 14 dari 222 negara terdampak Covid-19 dengan total kasus positif sebanyak 3.239.936 (Worldometers, 2021). Penyebaran Covid-19 yang telah meluas ke seluruh provinsi di Indonesia membawa dampak serius ke berbagai bidang, tak terkecuali pada bidang sosial-ekonomi. Hal ini melatarbelakangi pemilihan permasalahan sosial-ekonomi sebagai fokus Kebijakan Fiskal 2022. Dengan kebijakan tersebut, pemerintah melalui Kementerian Keuangan mencanangkan pemulihan sosial-ekonomi sebagai fondasi untuk menguatkan stabilitas ekonomi nasional Indonesia dengan target pertumbuhan ekonomi sebesar 5,2-5,8\% di tahun 2022 (Kementerian Keuangan RI, 2021).

Meskipun demikian, adanya berbagai kebijakan pemerintah untuk menekan angka kasus positif Covid19 seperti PSBB dan PPKM menyebabkan aktivitas ekonomi melambat dan daya beli masyarakat menurun. Data pertumbuhan ekonomi yang dirilis Badan Pusat Statistik (BPS) menunjukkan pertumbuhan ekonomi Indonesia pada triwulan II-2020 mengalami penurunan sebesar 5,32\% dibanding triwulan II-2019. Kondisi ini masih berlanjut hingga triwulan I-2021 dengan penurunan sebesar 0,74\% dibanding triwulan I-2020 (BPS, 
2021). Hal tersebut diperkuat dengan kajian BPS menggunakan berbagai sumber big data yang memperlihatkan bahwa dampak pandemi sangat besar di tiga bulan awal pandemi (BPS, 2020). Kegiatan ekonomi kemudian baru mampu bergerak kembali setelah pemerintah dan masyarakat melakukan berbagai adaptasi protokol kesehatan terutama di era new normal (BPS, 2020).

Untuk mendorong pemulihan ekonomi Indonesia di era pandemi, sebagai strategi jangka pendek, pemerintah melalui Kementerian Keuangan mengeluarkan kebijakan Pemulihan Ekonomi Nasional (PEN). Selain itu, untuk pemulihan ekonomi jangka panjang, Kementerian Keuangan telah berupaya membuat suatu fondasi pelaksanaan ekonomi hijau (green economy) di Indonesia (Kementerian Keuangan RI, 2021). Bappenas mendefinisikan pertumbuhan ekonomi hijau sebagai pertumbuhan ekonomi yang kuat dan ramah lingkungan. Hal ini sejalan dengan agenda perubahan iklim sebagai prioritas nasional ke-6 pada Rencana Konstruksi Jangka Menengah Nasional (RPJMN) 2020-2024 (Bappenas, 2020). Oleh karena itu, diperlukan pemodelan kondisi ekonomi Indonesia yang mempertimbangkan kondisi lingkungan sehingga dapat terlihat gambaran mengenai kondisi ekonomi hijau Indonesia khususnya di era pandemi.

Kondisi ekonomi hijau dapat ditinjau dari beberapa aspek seperti aktivitas ekonomi dan kualitas udara (Tucci, 2020). Pada era pandemi, aktivitas ekonomi tidak lepas dari kasus positif Covid-19 dan mobilitas penduduk (Parwoto, 2020). Hal ini menunjukkan bahwa variabel - variabel yang dapat menggambarkan kondisi ekonomi hijau Indonesia di era pandemi, seperti aktivitas ekonomi, kualitas udara, tingkat mobilitas penduduk, dan kasus positif Covid-19 dapat memiliki hubungan kausalitas satu sama lain. Bayesian Network merupakan metode yang cocok untuk digunakan dalam membangun pemodelan kondisi ekonomi hijau Indonesia di era pandemic karena model yang dibangun harus dapat mempertimbangkan hubungan kausalitas tiap variabel yang digunakan. Bayesian Network merupakan salah satu algoritma Artificial Intelligence (AI) yang memodelkan suatu permasalahan dengan menggunakan directed acyclic graph (DAG), model ini mempertimbangkan hubungan kausalitas antar variabel yang digunakan (Horný, 2014). Pembentukan struktur DAG dapat dilakukan secara otomatis (automatic learning) atau melalui konstruksi manual dengan mengaplikasikan algoritma tertentu. Bayesian Network dapat dikonstruksi dengan menggunakan data diskrit, $K$-Means meruapakan salah satu algoritma yang biasa digunakan untuk diskretisasi data.

Data yang dapat menggambarkan aktivitas ekonomi dan kualitas udara dapat diperoleh melalui big data. Penelitian terkait penggunaan big data seperti data penginderaan jarak jauh intensitas cahaya malam dalam menggambarkan aktivitas ekonomi di suatu wilayah pada era pandemi telah beberapa kali dilakukan. Anand dan Kim (2021) menunjukkan bahwa kebijakan lockdown akibat pandemi Covid-19 di Afrika berdampak pada penurunan aktivitas ekonomi yang terlihat dari penurunan intensitas cahaya malam. Michael Hudecheck, Charlotta Sirén \& Wincent (2020) menunjukkan bahwa penginderaan cahaya malam melalui satelit dapat secara efektif menunjukkan kegiatan ekonomi di Swiss selama pandemi. Selain itu, penelitian terkait kondisi lingkungan khususnya kualitas udara di era pandemi juga telah beberapa kali dilakukan. Srikanta Sannigrahi et al., (2021) yang meneliti dua puluh kota besar dengan jumlah kasus positif Covid-19 tinggi di Benua Amerika dan Eropa menunjukkan bahwa terkendalinya polusi dari lalu lintas kendaraan bermotor dan terbatasnya aktivitas manusia saat masa lockdown pandemi Covid-19 adalah cara efektif dalam meningkatkan kualitas udara di suatu wilayah. Senada dengan penelitian tersebut, Kazakos et al., (2021) melalui penelitiannya juga memperoleh kesimpulan bahwa Covid-19 secara tidak langsung meningkatkan kualitas udara di Kota London saat diberlakukannya lockdown di kota tersebut. Di Indonesia, dengan pendekatan big data, Pramana et al., (2020) menunjukkan adanya perbaikan kualitas udara di beberapa wilayah terutama episentrum pandemi Indonesia yaitu Jabodetabek.

Berdasarkan uraian di atas, untuk mendorong kesuksesan kebijakan dan program pemerintah terkait pemulihan sosial-ekonomi Indonesia khususnya dalam pemulihan ekonomi jangka pendek dan jangka panjang, penelitian ini bertujuan untuk menerapkan pendekatan Bayesian Network dalam menggambarkan kondisi ekonomi hijau Indonesia berdasarkan big data. Penelitian ini diharapkan dapat memberikan gambaran mengenai keterkaitan antara kondisi ekonomi (dalam hal ini PDRB) dengan aktivitas ekonomi, kualitas udara, tingkat mobilitas penduduk, dan kasus positif Covid-19. Gambaran mengenai kondisi ekonomi hijau Indonesia ini diharapkan dapat menjadi dasar pengambilan keputusan bagi para pemangku kepentingan sehingga usaha pemulihan sosial-ekonomi Indonesia dapat lebih efektif.

\section{METODOLOGI}

\section{Data dan Sumber Data}

Terdapat lima jenis data yang digunakan pada penelitian ini, yaitu data PDRB, data kasus positif Covid19, data mobilitas penduduk, data intensitas cahaya malam atau nighttime light intensity (NTL) yang 
menggambarkan aktivitas ekonomi, dan data kualitas udara. Tabel 1 menunjukkan deskripsi data yang digunakan pada penelitian ini.

Tabel 1. Deskripsi Variabel yang Digunakan pada Penelitian

\begin{tabular}{|c|c|c|c|c|}
\hline Variabel & Satuan & Cakupan Waktu & $\begin{array}{l}\text { Cakupan } \\
\text { Wilayah }\end{array}$ & Sumber Data \\
\hline PDRB & Rupiah & $\begin{array}{l}\text { Triwulan (Triwulan I } 2020 \\
\text { - Triwulan I 2021) }\end{array}$ & \multirow{7}{*}{$\begin{array}{l}34 \text { Provinsi } \\
\text { Indonesia }\end{array}$} & BPS \\
\hline $\begin{array}{l}\text { Kasus positif Covid-19 } \\
\text { (covid) }\end{array}$ & Orang & $\begin{array}{c}\text { Harian (15 Maret 2020 - } \\
31 \text { Maret 2021) }\end{array}$ & & KawalCovid \\
\hline $\begin{array}{l}\text { Mobilitas ke Tempat Kerja } \\
\text { (mob.work) } \\
\text { Mobilitas ke Tempat Tinggal } \\
\text { (mob.resident) }\end{array}$ & \multirow{3}{*}{$\begin{array}{l}\text { Persen dari } \\
\text { Baseline }\end{array}$} & & & \\
\hline $\begin{array}{l}\text { Mobilitas ke Tempat Belanja } \\
\text { (mob.grocery) } \\
\text { Mobilitas Taman (mob.park) } \\
\text { Mobilitas ke Tempat Transit } \\
\text { (mob.trans) }\end{array}$ & & $\begin{array}{c}\text { Harian (15 Februari } 2020- \\
31 \text { Maret 2021) }\end{array}$ & & Google Mobility Index \\
\hline $\begin{array}{c}\text { Mobilitas ke Perdagangan } \\
\text { Retail dan Rekreasi } \\
\text { (mob.retail) }\end{array}$ & & & & \\
\hline Kualitas Udara (AQI) & (Indeks) & $\begin{array}{c}3 \text { jam (15 Maret 2020 - } 31 \\
\text { Maret 2021) }\end{array}$ & & $\begin{array}{l}\text { Website Penyedia } \\
\text { Informasi Kualitas } \\
\text { Udara Dunia }\end{array}$ \\
\hline $\begin{array}{c}\text { Intensitas Cahaya Malam } \\
\text { (NTL) }\end{array}$ & nanoWatts/cm $2 / \mathrm{sr}$ & $\begin{array}{c}\text { Bulananan (Januari } 2020- \\
\text { Maret 2021) }\end{array}$ & & Satelit NOAA-VIIRS \\
\hline
\end{tabular}

1) Data PDRB

Data PDRB Indonesia yang digunakan pada penelitian ini adalah PDRB atas dasar harga berlaku untuk 34 provinsi di Indonesia pada triwulan I-IV 2020 dan triwulan I 2021 yang diperoleh dari laman resmi BPS (bps.go.id). Data diunduh dalam format xlsx.

2) Data Kasus positif Covid-19

Data kasus positif Covid-19 yang digunakan pada penelitian ini bersumber dari Kawal Covid19 yang menyediakan data jumlah kumulatif kasus positif harian Covid-19 di Indonesia untuk setiap provinsi. Data diunduh dalam format csv.

3) Data Mobilitas Penduduk

Data mobilitas penduduk yang digunakan pada penelitian ini diperoleh dari Google yang menyediakan Google Mobility Index atau indeks mobilitas yang menunjukkan persentase perubahan kunjungan seseorang ke beberapa tempat dalam satu hari terhadap baseline days. Nilai baseline merupakan median harian yang dihitung berdasarkan data kunjungan pada periode 3 Januari -6 Februari 2020. Indeks ini disajikan dalam bentuk persentase dan merupakan agregat dari data individu yang kunjungannya terekam di Google Maps. Terdapat enam kategori tempat kunjungan yang dicatat yaitu tempat kerja, tempat tinggal, tempat belanja (pasar dan supermarket), taman, tempat transit (stasiun dan terminal), dan tempat perdagangan retail dan rekreasi (mall, restoran, museum, perpustakaan, dan bioskop). Data diunduh dalam format csv.

4) Data Intensitas Cahaya Malam (Nighttime Light Intensity)

Data intensitas cahaya malam yang digunakan pada penelitian ini diperoleh dari citra satelit milik National Oceanic and Atmospheric Administration (NOAA) Amerika Serikat yang menggunakan teknologi Visible Infrared Imaging Radiometer Suite (VIIRS) untuk menangkap kecerahan (luminosity) suatu wilayah pada malam hari. Data kecerahan malam hari (night time lights; NTL) didapat melalui DNB (Day/Night Band). Data tersebut tersedia untuk setiap bulan dan diperoleh melalui aplikasi Google Earth Engine.

5) Data Kualitas Udara

Data kualitas udara yang digunakan pada penelitian ini adalah AQI (Air Quality Index). AQI adalah ukuran standar kualitas udara yang digunakan untuk menyatakan tingkat risiko kesehatan yang terkait dengan polusi udara partikulat dan gas. AQI menggambarkan kualitas udara menurut konsentrasi polutan udara utama seperti PM10, PM2.5, ozon, $\mathrm{SO}_{2}, \mathrm{NO}_{2}$, dan $\mathrm{CO}$. Semakin tinggi nilai AQI, semakin buruk kondisi udara di wilayah pengamatan. Data diperoleh dari salah satu website 
penyedia AQI dunia dengan metode scraping. Data yang dikumpulkan terdiri atas 6.268.934 records dan 22 variabel.

\section{Tahapan Penelitian}

Secara umum, terdapat sembilan tahapan yang dilakukan pada penelitian ini yaitu pengumpulan data, preprocessing data, analisis data eksploratif, integrasi data, penghitungan korelasi, konstruksi model Bayesian Network, pengecekan validasi model, pemilihan model terbaik, dan analisis hasil. Gambar 1 menunjukkan diagram alir penelitian ini.

1) Pengumpulan Data

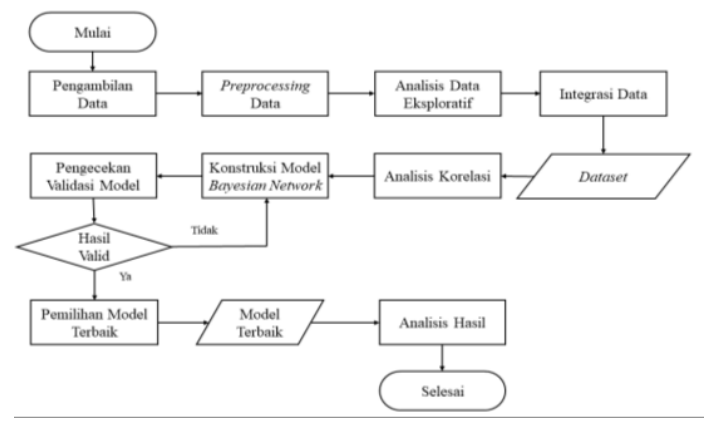

Gambar 1. Diagram Alir Penelitian

Data PDRB, data kasus harian Covid-19, dan data mobilitas penduduk diunduh dengan format xlsx atau csv dari sumber data yang sudah diuraikan pada poin sebelumnya. Data intensitas cahaya malam (nighttime light intensity; NTL) diperoleh melalui Google Earth Engine melalui pengkodean dengan bahasa pemrograman JavaScript. Proses dimulai dari penginputan file shp untuk mendefinisikan cakupan wilayah kemudian dilanjutkan dengan pengkodean untuk mengambil data intensitas cahaya malam pada band 'avg_rad'. Data kualitas udara (AQI) diperoleh dengan metode web scraping. Alat yang digunakan untuk melakukan web scraping adalah bahasa pemrograman Python dan package scrapy. Package scrapy dipilih karena open source, fleksibel, dan mampu mengekstrak dokumen HTML dengan memilih bagian tertentu (Rohman et al., 2019). Scraping data kualitas udara dilakukan setiap tiga jam sekali.

2) Preprocessing Data

Preprocessing data diperlukan untuk menyesuaikan data mentah yang dimiliki menjadi format yang dapat dianalisis. Preprocessing data paling banyak dilakukan yaitu pada data kualitas udara (AQI) karena merupakan hasil scraping. Preprocessing data yang dilakukan dalam penelitian ini di antaranya cleaning, penyesuaian format data frame, dan penggabungan data.

3) Analisis Data Eksploratif

Analisis data eksploratif dilakukan untuk mengeksplorasi data dengan berbagai cara sampai didapatkan "kisah" dibalik data tersebut. Pada penelitian ini, eksplorasi data dilakukan dengan melihat pola pada grafik.

4) Integrasi Data

Data yang digunakan pada penelitian berasal dari berbagai sumber dan disajikan dalam bentuk dan jangka waktu yang berbeda-beda. Integrasi data dilakukan dengan menyesuaikan seluruh data ke bentuk data triwulan untuk 34 provinsi. Data kualitas udara (AQI) yang didapatkan setiap tiga jam pada setiap stasiun pengamatan disesuaikan dengan mengambil nilai rata-rata. Data kasus positif Covid-19 dan mobilitas penduduk yang didapatkan dalam bentuk data harian untuk setiap provinsi juga disesuaikan dengan mengambil nilai rata-rata. Output dari proses ini adalah dataset yang siap dianalisis.

5) Penghitungan Korelasi

Penghitungan korelasi dilakukan untuk mengetahui keeratan hubungan antar variabel yang digunakan pada penelitian ini. Pada penelitian ini ukuran korelasi yang digunakan adalah korelasi Pearson karena seluruh data yang digunakan berskala interval dan rasio. Persamaan 1 menunjukkan formula untuk mendapatkan nilai koefisien korelasi $(r)$.

$$
\frac{n \sum X Y-\left(\sum X\right)\left(\sum Y\right)}{\sqrt{\left\{n \sum X^{2}-\left(\sum X\right)^{2}\right\}\left\{n \sum Y^{2}-\left(\sum Y\right)^{2}\right\}}} \ldots
$$

$$
r=
$$

dimana :

$X=$ nilai observasi variabel pertama 
$Y=$ nilai observasi variabel kedua

$n=$ banyak observasi

Koefisien korelasi $(r)$ berkisar antara 0 sampai 1. Arah hubungan ditunjukkan melalui tanda positif atau negatif. Tabel 2 menunjukkan pedoman untuk menginterpretasikan hasil koefisien korelasi $(r)$ menurut Sugiyono (2010).

Tabel 2. Interpretasi Koefisien Korelasi

\begin{tabular}{cc}
\hline Koefisien Korelasi & Interpretasi \\
\hline $0,00 \leq r \leq 0,199$ & Sangat Rendah \\
$0,2 \leq r \leq 0,399$ & Rendah \\
$0,4 \leq r \leq 0,599$ & Sedang \\
$0,6 \leq r \leq 0,799$ & Kuat \\
$0,8 \leq r \leq 1,000$ & Sangat Kuat \\
\hline
\end{tabular}

Sumber : Sugiyono, 2010

6) Konstruksi Model Bayesian Network

Bayesian Network adalah salah satu bentuk probabilistic graphical model (PGM) yang merepresentasikan hubungan probabilistik kausal di antara sekumpulan variabel acak, dependensi kondisional, dan memberikan representasi lengkap dari joint probability distribution. Bayesian Network terdiri atas dua bagian utama yaitu directed acyclic graph (DAG) dan sekumpulan conditional probability distribution (CPT). Jika terdapat dependensi kausal probabilistik di antara dua random variabel pada graph, node yang berkorespondensi akan dihubungkan dengan busur berarah (directed edge). Kelebihan algoritma Bayesian Network adalah dapat digunakan dalam pembangunan model prediktif dan deskriptif. Sebagai alat prediksi, model ini memberikan alat yang efisien untuk memecahkan berbagai permasalahan inferensia termasuk di antaranya posterior probability, abductive atau diagnostic reasoning, analisis relevansi, dan klasifikasi. Pada kasus deskripsi, model ini dapat mendeskripsikan hubungan dependensi antar variabel dan menyusun domain masalah yang dimodelkan. Konstruksi model Bayesian Network dapat dilakukan melalui dua cara yaitu konstruksi manual dan automatic learning. Konstruksi manual dilakukan dengan mengidentifikasi nodes (variabel) yang relevan dan dependensi struktural di antaranya. Automatic learning dilakukan dengan membangun struktur Bayesian Network dengan suatu algoritma yang diaplikasikan pada sebuah dataset (Horný, 2014). Gambar 2 menunjukkan diagram alir konstruksi Bayesian Network yang dilakukan.

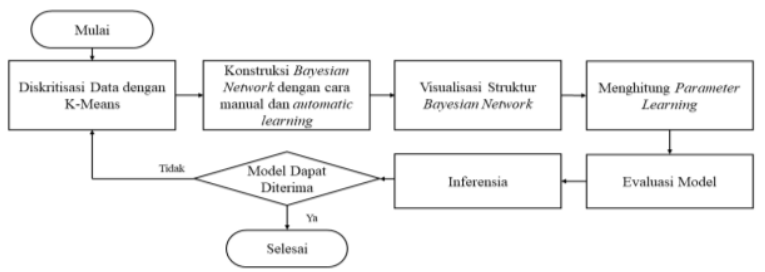

Gambar 2. Diagram Alir Konstruksi Model Bayesian Network

Proses konstruksi model Bayesian Network dimulai dari diskretisasi data dengan menggunakan algoritma $\mathrm{K}$-Means. $\mathrm{K}$-Means merupakan algoritma yang menetapkan suatu objek ke dalam cluster yang mempunyai centroid terdekat (Febrianti et al., 2018). Berikut adalah langkah-langkah pembentukan klaster pada algoritma $K$-Means.

1. Memilih nilai $k$ (jumlah kelompok) dengan Elbow Method yang memberikan informasi terkait kebaikan jumlah klaster berdasarkan nilai sum of square error (SSE).

2. Menetapkan centroid berdasarkan rata-rata setiap kelompok.

3. Mengelompokkan setiap data menurut centroid terdekat, penghitungan jarak dilakukan dengan fungsi jarak Euclid pada persamaan 2.

$$
d(c, t)=\sqrt{\left(c_{x}-t_{x}\right)\left(c_{y}-t_{y}\right)}
$$

dimana $c$ adalah centroid dan $t$ adalah data.

4. Untuk setiap kelompok baru yang dibentuk, dihitung kembali nilai centroid untuk menjadi centroid baru.

5. Membentuk kelompok baru yang lebih stabil dengan mengulang langkah ke-2 hingga ke-4.

6. Melakukan profiling untuk menginterpretasikan pengelompokan yang dibentuk. 
Pada penelitian ini diimplementasikan dua cara konstruksi model Bayesian Network yaitu konstruksi manual dan automatic learning. Konstruksi manual dilakukan dengan menggunakan algoritma Maximum Spanning Tree berdasarkan hubungan kausal. Keeratan hubungan kausal diperoleh berdasarkan nilai korelasi Pearson yang dipilih sebagai bobot. Untuk membangun spanning tree pada penelitian ini, digunakan algoritma prim dengan langkah-langkah sebagai berikut.

1. Menghubungkan dua variabel dengan nilai koefisien korelasi terbesar.

2. Menghubungkan variabel lain yang memiliki koefisien korelasi yang terbesar berikutnya dengan syarat tidak membentuk siklus.

3. Mengulang langkah ke-2 hingga terbentuk spanning tree yang menghubungkan seluruh variabel.

Konstruksi Bayesian Network dengan automatic learning dilakukan dengan mengimplementasikan algoritma Hill Climbing dengan penilaian (scoring) K2. Hill Climbing adalah algoritma local search yang menelusuri search space dengan memulai dari initial solution dan melakukan serangkaian langkah sampai ditemukan solusi untuk memaksimumkan nilai fungsi. Pada konstruksi Bayesian Network, langkah yang diambil di antaranya penambahan busur, penghapusan busur, dan pembalikan busur pada directed acyclic graph (DAG) (Gamez \& Mateo, 2011). Seluruh proses konstruksi Bayesian Network dilakukan dengan menggunakan software RStudio.

7) Pengecekan Validasi Model

Pengecekan validasi dilakukan untuk melihat seberapa valid model yang dibangun. Pengecekan dilakukan dengan mengimplementasikan metode K-Fold Cross Validation. Beberapa ukuran kebaikan model yang digunakan sebagai evaluasi di antaranya akurasi, sensitivitas, dan spesifisitas. Persamaan 3, 4, dan 5 menunjukkan formula untuk menghitung akurasi, sensitivitas, dan spesifisitas (Zhu, 2010). Akurasi $=$

\begin{tabular}{|c|}
\hline 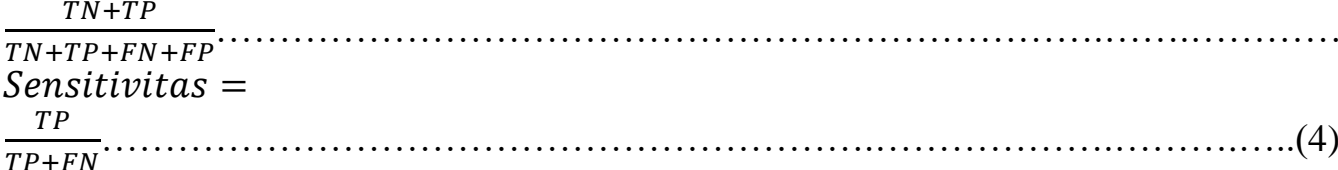 \\
\hline $\begin{array}{l}\text { SP+FN } \\
\text { Spesifisitas }=\end{array}$ \\
\hline $\begin{array}{l}\text { dimana }: \\
T N=\text { banyak prediksi benar negatif } \\
T P=\text { banyak prediksi benar positif } \\
F N=\text { banyak prediksi salah negatif } \\
F P=\text { banyak prediksi salah positif } \\
\text { Pemilihan Model Terbaik }\end{array}$ \\
\hline
\end{tabular}

Berdasarkan uji validasi yang telah dilakukan sebelumnya, dipilih model terbaik dengan memperhatikan beberapa penilaian yaitu akurasi, sensitivitas, dan spesifisitas. Semakin baik nilai akurasi, sensitivitas, dan spesifisitas, semakin baik pula model tersebut dalam merepresentasikan data.

9) Analisis Hasil

Berdasarkan model terbaik yang dipilih, dilakukan analisis untuk mendapat gambaran deskriptif model yang diperoleh. Analisis dilakukan dengan memperhatikan Conditional Probability Table (CPT) yang diperoleh berdasarkan model terbaik.

\section{HASIL DAN PEMBAHASAN}

\section{Hasil Penghitungan Korelasi Pearson}

Korelasi Pearson digunakan untuk mengukur kekuatan hubungan antar variabel yang nantinya digunakan sebagai bobot dalam konstruksi Bayesian Network dengan algoritma Maximum Spanning Tree. Data yang digunakan dalam penghitungan ini adalah data numerik triwulan seluruh provinsi di Indonesia. Gambar 3 menunjukkan hasil penghitungan korelasi Pearson. 


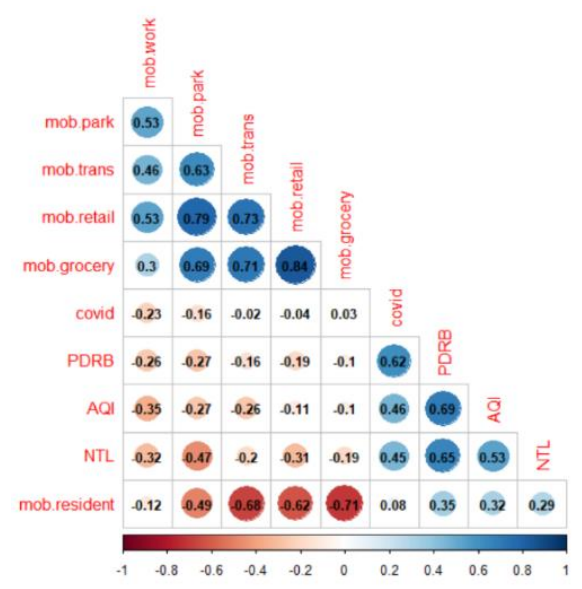

Gambar 3. Korelasi Antar Variabel

Berdasarkan penghitungan korelasi pada Gambar 3, dapat terlihat bahwa variabel PDRB berkorelasi positif kuat dengan tiga variabel lainnya yaitu variabel Covid-19 dengan nilai $r=0,62$, variabel intensitas cahaya malam yang menandakan aktivitas ekonomi (NTL) dengan nilai $r=0,65$, dan variabel kualitas udara (AQI) dengan nilai $r=0,69$. Hal ini mengindikasikan bahwa kenaikan nilai PDRB juga sejalan dengan kenaikan kasus positif Covid-19, nilai intensitas cahaya malam, dan nilai indeks kualitas udara (AQI) secara kuat. Provinsi dengan PDRB tinggi cenderung memiliki kasus positif Covid-19 yang tinggi, aktivitas ekonomi yang tinggi, dan kualitas udara yang buruk. Variabel AQI berkorelasi positif sedang dengan dua variabel yaitu variabel NTL dengan $r=0,53$ dan variabel kasus positif Covid-19 dengan $r=0,46$. Hal ini menunjukkan bahwa kenaikan nilai AQI sejalan dengan kenaikan nilai NTL dan nilai kasus positif Covid-19 secara sedang. Provinsi dengan kualitas udara buruk cenderung memiliki aktivitas ekonomi dan kasus positif Covid-19 yang tinggi. Variabel NTL berkorelasi positif sedang dengan variabel kasus positif Covid-19 dengan $r=0,45$. Hal ini menunjukkan bahwa kenaikan nilai NTL sejalan dengan kenaikan variabel kasus positif Covid-19. Provinsi dengan aktivitas ekonomi tinggi cenderung memiliki kasus positif Covid-19 yang tinggi juga. Variabelvariabel mobilitas berkorelasi kuat dan sedang satu sama lain tetapi berkorelasi rendah atau sangat rendah dengan variabel lainnya. Karena tidak dapat merepresentasikan variabel lain, variabel-variabel mobilitas tidak digunakan dalam pemodelan Bayesian Network.

\section{Hasil Diskretisasi Data}

Diskretisasi $K$-Means diterapkan pada variabel - variabel yang memiliki bobot tinggi atau berkorelasi kuat atau sedang satu sama lain yaitu kasus positif Covid-19, intensitas cahaya malam (NTL), kualitas udara (AQI), dan PDRB. Diskretisasi dilakukan dengan mengelompokkan data berdasarkan jarak dengan tiap centroid masing-masing kelompok. Pemilihan jumlah kelas didasarkan pada Elbow Method yang memberikan informasi terkait kebaikan jumlah klaster berdasarkan nilai sum of square error (SSE). Centroid tiap kelompok didapat dari penghitungan rata-rata (mean) masing-masing kelompok data. Proses tersebut dilakukan secara berulang dan berhenti ketika kategori yang terbentuk sudah stabil. Terakhir, profiling dilakukan untuk menginterpretasikan hasil diskretisasi. Tabel 3 menunjukkan hasil profiling diskretisasi yang dilakukan.

Tabel 3. Hasil Diskretisasi Data

\begin{tabular}{|c|c|c|c|c|c|}
\hline No. & Variabel & Hasil Diskretisasi & No. & Variabel & Hasil Diskretisasi \\
\hline \multirow[t]{4}{*}{1.} & Kasus positif & Sangat Tinggi & 3. & Kualitas Udara & Sangat Tinggi \\
\hline & Covid-19 (covid) & Tinggi & & (AQI) & Tinggi \\
\hline & & Rendah & & & Rendah \\
\hline & & Sangat Rendah & & & Sangat Rendah \\
\hline \multirow[t]{4}{*}{2.} & Intensitas Cahaya & Sangat Tinggi & 4. & PDRB & Sangat Tinggi \\
\hline & Malam (NTL) & Tinggi & & & Tinggi \\
\hline & & Rendah & & & Rendah \\
\hline & & Sangat Rendah & & & Sangat Rendah \\
\hline
\end{tabular}

\section{Konstruksi Model Bayesian Network}

Data yang sudah dideskritisasi kemudian digunakan untuk membangun konstruksi model Bayesian Network dengan menggunakan dua cara yaitu konstruksi manual dan automatic learning. Konstruksi manual dilakukan dengan mengimplementasikan algoritma Maximum Spanning Tree berdasarkan hubungan kausal. 
Konstruksi dengan automatic learning dilakukan dengan mengimplementasikan algoritma Hill Climbing dengan scoring K2. Pada penelitian ini, diperoleh hasil yang berbeda pada kedua cara konstruksi tersebut.

1) Hasil Konstruksi Manual dengan Algoritma Maximum Spanning Tree

Algoritma Maximum Spanning Tree diimplementasikan berdasarkan hubungan kausal. Keeratan hubungan kausal diperoleh melalui nilai korelasi Pearson yang dipilih sebagai bobot. Variabel kualitas udara (AQI) dan PDRB merupakan dua variabel pertama yang dihubungkan karena memiliki nilai korelasi Pearson paling tinggi. Kemudian, variabel-variabel lain juga dihubungkan berdasarkan nilai korelasi Pearson. Hasil konstruksi Bayesian Network menggunakan algoritma Maximum Spanning Tree dengan pembobot korelasi Pearson digambarkan melalui directed acyclic graph (DAG) pada Gambar 4.

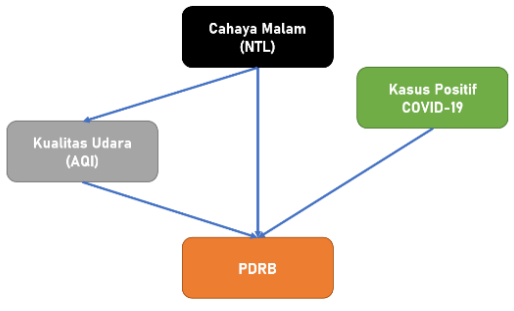

Gambar 4. DAG Konstruksi Manual Bayesian Network dengan Algoritma Maximum Spanning Tree

Berdasarkan DAG pada Gambar 4, dapat terlihat bahwa variabel yang secara langsung berpengaruh terhadap PDRB adalah NTL (intensitas cahaya malam yang menunjukkan aktivitas ekonomi), AQI (kualitas udara), dan kasus positif Covid-19. Selain itu, variabel NTL juga secara langsung berpengaruh terhadap kualitas udara.

2) Hasil Konstruksi Automatic Learning dengan Algoritma Hill Climbing

Pada konstruksi Bayesian Network dengan automatic learning, algoritma Hill Climbing diimplementasikan dengan menggunakan K2 scoring. Implementasi algoritma dilakukan menggunakan library 'bn_learn' pada software Rstudio. Hasil yang diperoleh digambarkan melalui directed acyclic graph (DAG) pada Gambar 5.

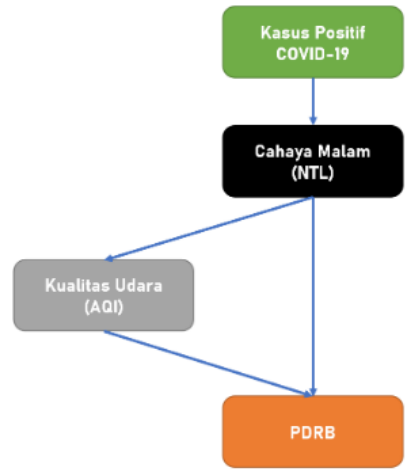

Gambar 5. DAG Konstruksi Automatic Learning Bayesian Network dengan Algoritma Hill Climbing Mengimplementasi K2 Scoring

Berdasarkan DAG pada Gambar 5, dapat terlihat bahwa variabel yang secara langsung berpengaruh terhadap PDRB adalah NTL (intensitas cahaya malam yang menunjukkan aktivitas ekonomi) dan kualitas udara (AQI). Selain itu, variabel NTL juga secara langsung berpengaruh terhadap kualitas udara (AQI).

\section{Evaluasi Hasil Konstruksi Model Bayesian Network}

Evaluasi hasil konstruksi model Bayesian Network dilakukan untuk mendapatkan model terbaik yang menggambarkan kondisi ekonomi hijau Indonesia di masa pandemi berdasarkan empat kelas PDRB (sangat rendah, rendah, tinggi, dan sangat tinggi). Evaluasi dilakukan dengan teknik 5-Cross Validation. 5-Cross Validation dilakukan dengan membagi data ke dalam 5-subset. Kemudian, dilakukan pengulangan sebanyak lima kali untuk training (pembelajaran model) dan testing (pengujian model). Evaluasi dilakukan berdasarkan ukuran kebaikan model yaitu akurasi, sensitivitas, dan spesifisitas yang dijelaskan pada persamaan 3, 4, dan 5. Pengukuran nilai akurasi, sensitivitas, dan spesifisitas dilakukan untuk setiap kelas. Tabel 5 menunjukkan rata-rata setiap ukuran untuk setiap kelas. 
Tabel 5. Evaluasi Hasil Konstruksi Model Bayesian Network dengan 5-Cross Validation

\begin{tabular}{ccc}
\hline Ukuran Kebaikan Model & $\begin{array}{c}\text { Model 1 } \\
\text { (Maximum Spanning Tree) }\end{array}$ & $\begin{array}{c}\text { Model 2 } \\
\text { (Hill Climbing dengan K2 } \\
\text { Scoring) }\end{array}$ \\
\hline Akurasi & 0,83 & 0,8 \\
Sensitivitas (rata-rata dari setiap kelas) & 0,67 & 0,66 \\
Spesifisitas (rata-rata dari setiap kelas) & 0,88 & 0,86 \\
\hline
\end{tabular}

Berdasarkan Tabel 5, dapat terlihat bahwa Model 1 (Maximum Spanning Tree) memliki nilai akurasi, sensitivitas, dan spesifisitas yang lebih besar dari Model 2 (Hill Climbing dengan K2 Scoring). Oleh karena itu, Model 1 dipilih sebagai model terbaik dalam penelitian ini.

\section{Analisis Parameter Bayesian Network pada Model Terbaik}

Berdasarkan model terbaik yang dipilih, dilakukan analisis parameter learning untuk mendapat gambaran yang lebih jelas mengenai kondisi ekonomi hijau Indonesia di era pandemi. Analisis parameter learning dilakukan dengan melihat Conditional Probability Table (CPT) pada node yang menjadi fokus penelitian ini yaitu PDRB. Gambar 6 menunjukkan CPT node PDRB.

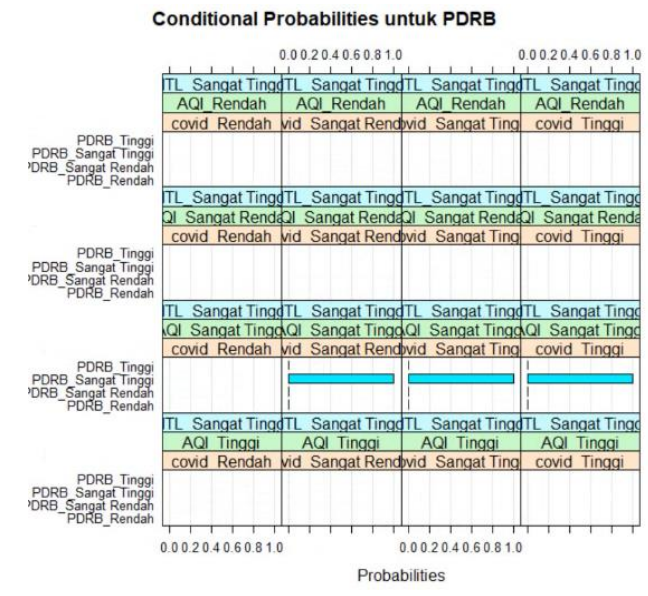

Gambar 6a. NTL Sangat Tinggi

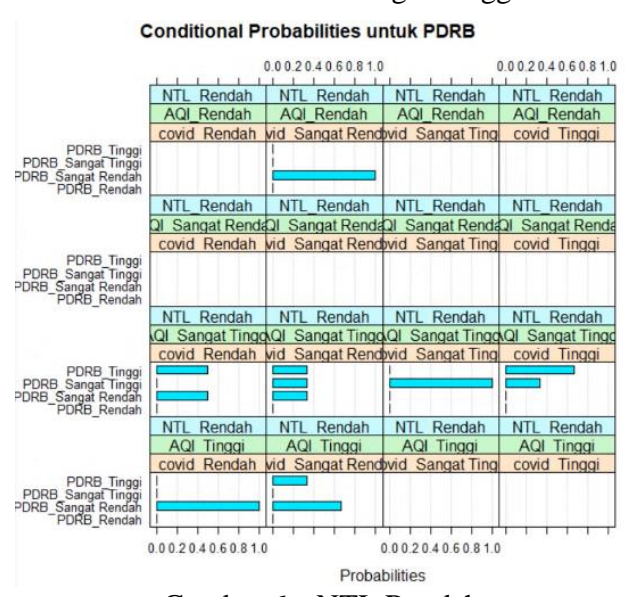

Gambar 6c. NTL Rendah

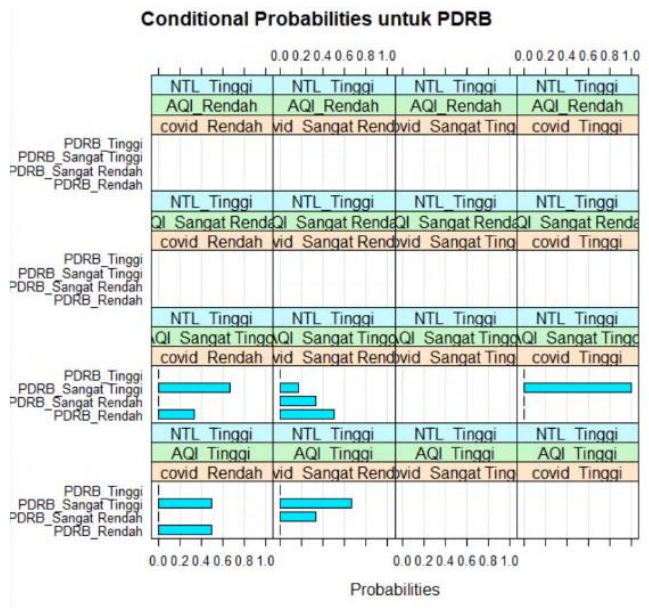

Gambar 6b. NTL Tinggi Conditional Probabilities untuk PDRB

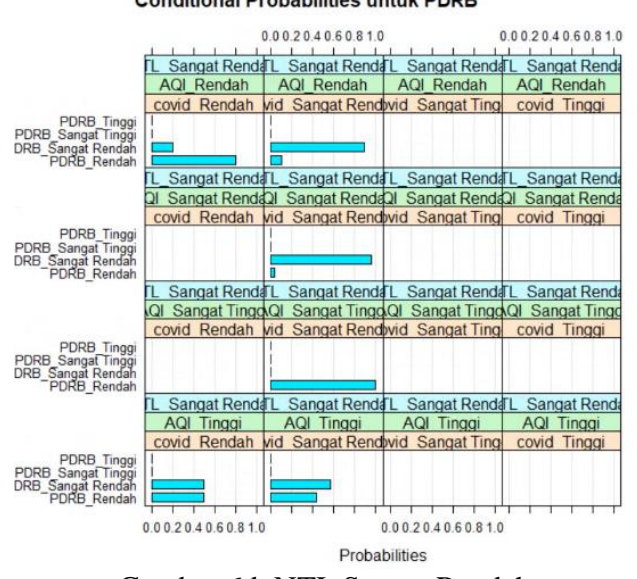

Gambar 6d. NTL Sangat Rendah

Gambar 6. CPT node PDRB

Secara umum, Gambar 6 memperlihatkan bahwa provinsi-provinsi dengan kasus positif Covid-19 tinggi atau sangat tinggi memiliki peluang besar untuk memiliki nilai PDRB tinggi atau sangat tinggi juga. Provinsiprovinsi dengan peluang memiliki PDRB yang tinggi atau sangat tinggi cenderung memiliki nilai NTL dan AQI yang tinggi atau sangat tinggi. Tingginya nilai AQI pada provinsi dengan PDRB tinggi memperlihatkan bahwa kualitas udara pada provinsi tersebut masih belum terpelihara dengan baik. Hal ini menunjukkan bahwa pertumbuhan ekonomi provinsi-provinsi Indonesia di era pandemi masih cenderung belum sejalan dengan terpeliharanya kondisi lingkungan khususnya kualitas udara. Dengan demikian, usaha untuk mencapai kondisi ekonomi hijau yang mengharapkan pertumbuhan ekonomi yang ramah lingkungan perlu ditingkatkan. 


\section{KESIMPULAN}

Berdasarkan penelitian yang dilakukan, dapat disimpulkan bahwa terdapat korelasi yang positif kuat antara PDRB dengan NTL (intensitas cahaya malam yang menandakan aktivitas ekonomi), AQI (indeks kualitas udara), dan kasus positif Covid-19. Variabel - variabel mobilitas penduduk berkorelasi kuat satu sama lain tetapi berkorelasi rendah dan sangat rendah dengan variabel - variabel lainnya. Model Bayesian Network yang dipilih sebagai model terbaik adalah model yang dikonstruksi secara manual dengan mengaplikasikan algoritma Maximum Spanning Tree. Rata-rata akurasi 5-Cross Validation yang diperoleh dari model tersebut untuk memprediksi PDRB adalah 0,83 . Hasil analisis model terbaik yang dipilih menunjukkan bahwa kondisi ekonomi Indonesia secara langsung dipengaruhi oleh intensitas cahaya malam (NTL) yang menunjukkan aktivitas ekonomi, kualitas udara (AQI), dan kasus positif Covid-19. Hasil analisis parameter learning dengan CPT menunjukkan bahwa provinsi-provinsi dengan peluang memiliki PDRB yang tinggi atau sangat tinggi cenderung memiliki nilai NTL dan AQI yang tinggi atau sangat tinggi juga. Hal ini menunjukkan bahwa pertumbuhan ekonomi provinsi-provinsi Indonesia masih cenderung belum sejalan dengan terpeliharanya kondisi lingkungan khususnya kualitas udara. Dengan demikian, usaha untuk mencapai kondisi ekonomi hijau yang mengharapkan pertumbuhan ekonomi yang ramah lingkungan masih harus ditingkatkan.

\section{DAFTAR PUSTAKA}

Anand, A., \& Kim, D.-H. (2021). Pandemic Induced Changes in Economic Activity around African Protected Areas Captured through Night-Time Light Data. Remote Sens, $13(2), \quad 314$. https://doi.org/https://doi.org/10.3390/rs13020314

Badan Perencanaan Pembangunan Nasional (Bappenas). (2020). Rencana Pembangunan Jangka Menengah Nasional (RPJMN) 2020-2024 : Indonesia Berpenghasilan Menengah - Tinggi yang Sejahtera, Adil, dan Berkesinambungan. Kementerian PPN/Bappenas RI.

Badan Pusat Statistik. (2020). Analisis Big Data di Tengah Masa Adaptasi Kebiasaan Baru. Publikasi BPS. DKI Jakarta, Indonesia. Cited https://www.bps.go.id/publication/2020/08/14/6a0041243eb246d555e6d117/analisis-big-data-ditengahmasa-adaptasi-kebiasaan-baru.html [10 Agustus 2021]

Badan Pusat Statistik. (2020). Tinjauan Big Data Terhadap Dampak COVID-19. Publikasi BPS. DKI Jakarta, Indonesia. Cited in https://www.bps.go.id/publication/2020/06/01/effd7bb05be2884fa460f160/tinjauan-bigdata-terhadap-dampak-Covid-19-2020.html [10 Agustus 2021]

Febrianti, A. F., Cabral, A. H., \& Anuraga, G. (2018). K-Means Clustering dengan Metode Elbow Untuk Pengelompokan Kabupaten dan Kota di Jawa Timur Berdasarkan Indikator Kemiskinan. SNHRP.

Gámez, J. A., Mateo, J. L., \& Puerta, J. M. (2011). Learning Bayesian networks by hill climbing: efficient methods based on progressive restriction of the neighborhood. Data Mining and Knowledge Discovery, 22(1), 106-148. https://doi.org/10.1007/s10618-010-0178-6

Horný, M. (2014). Bayesian Networks. Boston University School of Public Health.

Kazakos, L., Taylor, J., \& Luo, Z. (2021). Impact of COVID-19 lockdown on NO2 and PM2.5 exposure inequalities in London, UK. Environmental Research, 198, 111236. https://doi.org/https://doi.org/10.1016/j.envres.2021.

Kementerian Keuangan RI. (2021). Kebijakan Fiskal 2022: Mendukung Pemulihan Dan Reformasi. DKI Jakarta, Indonesia. Cited in https://www.kemenkeu.go.id/publikasi/siaran-pers/siaran-pers-kebijakan-fiskal-2022mendukung-pemulihan-dan-reformasi/ [9 Agustus 2021]

Kementerian Keuangan RI. (2021). Transformasi Ekonomi Hijau untuk Masa Depan Peradaban. Berita Kemenkeu. DKI Jakarta, Indonesia. Cited in : kemenkeu.go.id [8 Agustus 2021]

Hudecheck, M., Sirén, C., Grichnik, D., \& Wincent, J. (2020). Monitoring the COVID-19 crisis from space. MIT Sloan Management Review.

Pramana, S., Paramartha, D. Y., Adhinugroho, Y., \& Nurmalasari, M. (2020). Air Pollution Changes of Jakarta, Banten, and West Java, Indonesia During the First Month of COVID-19 Pandemi. The Journal of Business Economics and Environmental Studies 10 (4), 15-19. https://doi.org/The Journal of Business Economics and Environmental Studies 10

Prawoto, N., Priyo Purnomo, E., \& Az Zahra, A. (2020). The Impacts of Covid-19 Pandemic on Socio-Economic Mobility in Indonesia. International Journal of Economics \& Business Administration (IJEBA).

Rohman, M. S., Santoso, H. A., Saraswati, G. W., \& Winarsih, N. A. S. (2019, November). Pemanfaatan TopicFocused Crawler untuk Pembangunan Corpus Berita Bencana menggunakan Teknik Scrapy CSS Selector. In SEMINAR NASIONAL APTIKOM (SEMNASTIK) 2019 (pp. 250-258).

Srikanta Sannigrahi, Prashant Kumar, Anna Molter, Qi Zhang, Bidroha Basu, Arunima Sarkar Basu, F. P. (2021). Examining the status of improved air quality in world cities due to COVID-19 led temporary reduction in 

anthropogenic
emissions.
Environmental
Research,
196. https://doi.org/https://doi.org/10.1016/j.envres.2021.110927

Sugiyono. (2008). Metode penelitian pendidikan:(pendekatan kuantitatif, kualitatif dan R \& D). Bandung: Alfabeta.

Tucci, F., \& Battisti, A. (2020, May). Green Economy for Sustainable and Adaptive Architectures and Cities: Objectives, Guidelines, Measures, Actions. In IOP Conference Series: Earth and Environmental Science (Vol. 503, No. 1, p. 012022). IOP Publishing.

Worldometers. (2021). Report Coronavirus Cases. COVID-19 Corona Virus Pandemic. https://www.worldometers.info/coronavirus/

Zhu, W., Zeng, N., \& Wang, N. (2010). Sensitivity, specificity, accuracy, associated confidence interval and ROC analysis with practical SAS implementations. NESUG proceedings: health care and life sciences, Baltimore, Maryland, 19, 67. 